Reprod. Nutr. Dévelop., 1983, 23 (5), 829-835.

\title{
Influence of dietary intake and weight variation on LH release after a gonadotrophin-releasing hormone (GnRH) injection during the post-partum period of the nursing cow
}

\author{
D. GAUTHIER (*), P. MAULÉON
}

Station de Physiologie de la Reproduction, I.N.R.A., Nouzilly 37380 Monnaie, France.

Summary. The experiment was conducted to measure the effects of restricting dietary intake on $\mathrm{LH}$ release following a $\mathrm{GnRH}$ injection during the post-partum period in nursing cows. Eighteen multiparous Charolais cows were fed a low ration from 45 days pre-partum to 45 days post-partum, and received an intravenous injection of synthetic $\mathrm{GnRH}(55 \mu \mathrm{g})$ at 5,15 and 30 days post-partum. Plasma LH concentration was measured during the $4 \mathrm{hrs}$ following each injection.

The cows were separated into 2 groups depending on whether their mean daily gain was negative (group 1) or positive (group 2).

The peak plasma LH concentration and the total release of $\mathrm{LH}$ after a $\mathrm{GnRH}$ injection tended to increase during the post-partum period irrespective of the group.

The maximum $\mathrm{LH}$ value and the total $\mathrm{LH}$ release following $\mathrm{GnRH}$ were higher in Group 1 than in Group 2 ( $p<0.05$ ), at 5, 15 and 30 days post-partum. Furthermore, the maximal plasma LH concentrations recorded after $\mathrm{GnRH}$ were highly correlated with the mean daily weight gain post-partum (day $15, r=-0.50$; day $30, r=-0.54$ ).

\section{Introduction.}

Undernutrition has been shown to reduce reproductive performance in beef cows as in many other species (Lamond, 1970). Low planes of nutrition result in delayed puberty (Duffour, 1975), reduced ovarian activity (Gauthier and Thimonier, 1982) and increase in the length of the post-partum anoestrous interval (Terqui et al., 1981). In the cow (Terqui et al., 1981) and the bull (Gauthier and Berbigier, 1982) underfeeding leads to a decrease in $\mathrm{LH}$ plasma concentrations, but the reasons for this decrease are unknown.

$\mathrm{LH}$ release from the anterior pituitary is controlled by the secretion of $\mathrm{GnRH}$ from the hypothalamus (Kaltenbach et al., 1974) and the pituitary response to $\mathrm{GnRH}$ is reduced during some physiological states, particularly during the postpartum period (Fernandes et al., 1978). Thus, the low LH concentrations in

${ }^{*}{ }^{*}$ Present adress : I.N.R.A., Theix, 63122 Ceyrat, France. 
underfed cattle may result from a decrease in the sensitivity of the pituitary to $\mathrm{GnRH}$. This experiment was therefore designed to investigate the influence of dietary restrictions (energy and nitrogen) on the $\mathrm{LH}$ response following $\mathrm{GnRH}$ injection in the post-partum nursing cow.

\section{Materials and methods.}

Forty-five days before the estimated calving time, 8 (first experiment) and 10 (second experiment) multiparous Charolais cows were fed a low plane of nutrition (table 1). This plane of nutrition was maintained until 45 days after calving. The animals, each suckling one calf, were housed in two parts of the same free stable and individual consumption depended on competition between the different females.

The cows were weighed fortnightly from 45 days pre-partum to 45 days postpartum. In addition, all females were weighed during the first 5 days postpartum. Females were checked for oestrus with the aid of a vasectomized bull twice a day (at 7 a.m. and 5 p.m.).

Five, 15 and 30 days after parturition, each cow received an intravenous injection of synthetic GnRH. After prior experimentation, a dose of $55 \mu \mathrm{g}$ was used to induce a small release of $\mathrm{LH}(<10 \mathrm{ng} / \mathrm{ml})$. Blood samples were collected $15 \mathrm{~min}$ before the injection and at $0,15,30,45,60,75,90,120,150,180,210$ and 240 min after injection ( 3 females on day 5 and 2 on day 30 were not sampled and are not included in the results). The cows were blood-sampled for plasma progesterone determination twice a week to detect the presence of corpora lutea (Thimonier, 1978).

Blood samples were immediately centrifuged and the plasma recovered and stored at $-20^{\circ} \mathrm{C}$ until subsequent assay.

A double antibody radioimmunoassay described by Pelletier (1972) was used to measure LH concentrations. This assay uses LH LER Reichert 1072-2 as a standard (1 $\mathrm{ng}$ LH LER $1072-2=2 \mathrm{ng}$ LH NIHS $)$ and assay sensitivity is

\section{TABLE 1}

Composition of the diet ( $\mathrm{kg}$ dry matter)

\begin{tabular}{cllll}
\hline Experiments & \multicolumn{3}{c}{ Pregnancy } & Lactation \\
\hline & & $3.4 \mathrm{~kg}$ hay & & $3.4 \mathrm{~kg}$ hay \\
& $11000 \mathrm{kcal}$ & $1.5 \mathrm{~kg}$ corn silage & $13000 \mathrm{kcal}$ & $1.5 \mathrm{~kg} \mathrm{corn}$ sillage \\
I & $485 \mathrm{gg}$ of & $1.7 \mathrm{~kg}$ lucerne & $675 \mathrm{~g}$ of & $2.8 \mathrm{~kg}$ lucerne \\
$(1978)$ & D.N. & $0.5 \mathrm{~kg}$ oats/barley & D.N. & $1.0 \mathrm{~kg}$ oats/barley \\
& & $1.5 \mathrm{~kg}$ corn & & $1.5 \mathrm{~kg}$ corn \\
II & $10500 \mathrm{kcal}$ & $2.5 \mathrm{~kg}$ corn silage & $13000 \mathrm{kcal}$ & $2.5 \mathrm{~kg}$ corn silage \\
$(1979)$ & $475 \mathrm{~g}$ of & $a d$ lib straw & $675 \mathrm{~g}$ of & ad lib straw \\
& D.N. & $1.4 \mathrm{~kg}$ lucerne & D.N. & $3.8 \mathrm{~kg}$ lucerne \\
\hline
\end{tabular}

D.N. : Digestible Nitrogen. 
$0.2 \mathrm{ng} / \mathrm{ml}$. Progesterone was quantified by a double antibody radioimmunoassay described by Yenikoye et al. (1981). The sensitivity of the assay was $0.1 \mathrm{ng} / \mathrm{ml}$ and the mean coefficient of variation was $10 \%$ for a value of $5 \mathrm{ng} / \mathrm{ml}$.

The total release of $\mathrm{LH}$ after each injection of $\mathrm{GnRH}$ was estimated by integration of the area below individual response curves from 0 to 4 hours after injection. The area is expressed as $\mathrm{ng} / \mathrm{ml} / 4 \mathrm{~h}$.

Maximal $\mathrm{LH}$ value after stimulation, total $\mathrm{LH}$ release and plasma $\mathrm{LH}$ concentrations before $\mathrm{GnRH}$ injection were analysed by split-plot analysis of variance. Missing data were estimated by the method described by Cochran and Cox (1968) for the split-plot analysis of variance.

\section{Results.}

The parameters studied were not significantly different $(p>0.3)$ between the 2 experiments, and the data were pooled for subsequent analysis.

The cows were divided into 2 groups :

- underfed cows : i.e. those whose weight decreased significantly during the first 45 days post-partum : group 1 (9 cows);

- normally-fed cows : i.e. those whose weight increased of remained static during the same period: groupe 2 (9 cows).

During the first 30 days post-partum the weight loss of group 1 was $310 \mathrm{~g} /$ day, whereas the weight gain of group 2 was $70 \mathrm{~g} /$ day $(\mathrm{p}<0.05)$.

No cows were in estrus before the last GnRH injection on the 30th day postpartum. Five cows from group 1 and 3 from the group 2 ovulated between the 15th and 30 th days post-partum. In each case the cycle was short $1<15$ days) ; progesterone concentrations were low (always under $3 \mathrm{ng} / \mathrm{ml}$ ) and did not differ between the two groups. When $\mathrm{GnRH}$ injection was given, progesterone concentration never exceeded $1 \mathrm{ng} / \mathrm{ml}$.

Luteinizing hormone increased $15 \mathrm{~min}$ after $\mathrm{GnRH}$ and peak concentrations were reached between 30 and $120 \mathrm{~min}$ after the injection, depending on the group and the number of days post-partum. The latency of the LH peak was proportional to its magnitude $(r=0.6 ; p<0.001)$.

There was no significant effect of a preceding ovulation or of any group-time interaction on the three parameters studied (plasma LH concentration before $\mathrm{GnRH}$ injection, maximal $\mathrm{LH}$ value after stimulation, total $\mathrm{LH}$ release ; table 2).

The mean plasma $\mathrm{LH}$ level before $\mathrm{GnRH}$ injection was lower in group 1 $(2.00 \mathrm{ng} / \mathrm{ml})$ than in group $2(2.16 \mathrm{ng} / \mathrm{ml})$, but did not differ significantly between the groups. It increased from day 5 to day 15 post-partum $(2.07$ to $2.21 \mathrm{ng} / \mathrm{ml}$ ) but then decreased on day $30(1.92 \mathrm{ng} / \mathrm{ml})$ in both groups (tables 2 and 3 ).

The effects of both group and time post-partum were significant for the other two parameters studied (table 2; fig. 1).

For each group, the $\mathrm{LH}$ response to $\mathrm{GnRH}$ injection during the post-partum period increased as estimated by both maximal LH value (from $5.67 \mathrm{ng} / \mathrm{ml}$ on day 5 to $24.24 \mathrm{ng} / \mathrm{ml}$ on day $30 ; \mathrm{p}<0.01$ ) and the total area under the response curve (from $57.1 \mathrm{ng} / \mathrm{ml} / 4 \mathrm{~h}$ on day 5 to $190.4 \mathrm{ng} / \mathrm{ml} / 4 \mathrm{~h}$ on day $30 ; p<0.01$; table 3). 
TABLE 2

Analysis of variance in split-plot design

\begin{tabular}{|c|c|c|c|c|}
\hline Source & d.f. & $\begin{array}{l}\text { Mean square } \\
\text { of LH level } \\
\text { pre-injection }\end{array}$ & $\begin{array}{c}\text { Mean square } \\
\text { of LH maximal } \\
\text { value }\end{array}$ & $\begin{array}{l}\text { Mean square } \\
\text { of total LH } \\
\text { release }\end{array}$ \\
\hline $\begin{array}{l}\text { Between-cow } \ldots \\
\text { Group } \ldots \ldots \ldots \ldots \\
\text { Error } \ldots \ldots \ldots \ldots\end{array}$ & $\begin{array}{c}(12) \\
1 \\
11\end{array}$ & $\begin{array}{l}0.454 \\
0.250\end{array}$ & $\begin{array}{c}1644.519^{*} \\
238.96\end{array}$ & $\begin{array}{r}148435.622^{*} \\
18833.260\end{array}$ \\
\hline 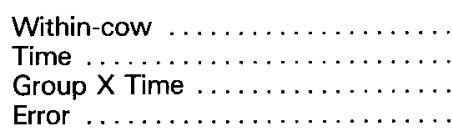 & $\begin{array}{c}(36) \\
2 \\
2 \\
32\end{array}$ & $\begin{array}{l}0.383^{*} \\
0.148 \\
0.114\end{array}$ & $\begin{array}{l}1670.310^{* *} \\
283.734 \\
127.789\end{array}$ & $\begin{array}{c}86549.480^{* *} \\
24941.497^{* *} \\
8752.629\end{array}$ \\
\hline
\end{tabular}

$$
{ }^{*}=\mathrm{p}<0.05 ;{ }^{* *}=\mathrm{p}<0.01 \text {. }
$$

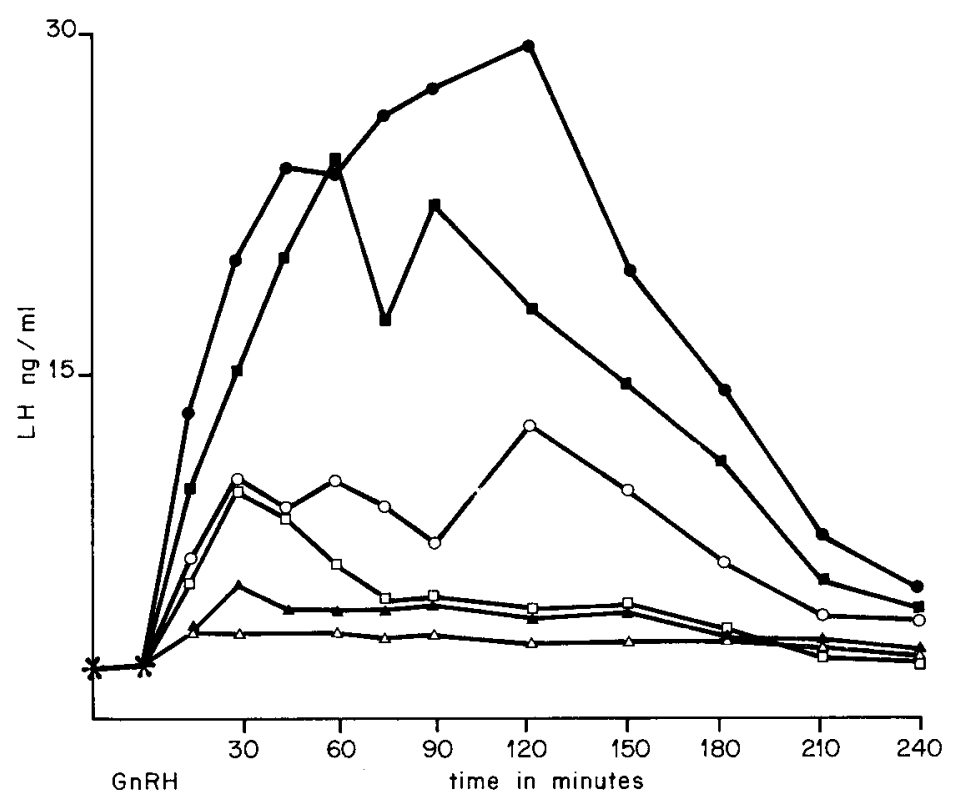

FIG. 1. - Post-partum profile of $L H$ release after a GnRH injection in cows losing weight (group 1) and in cows gaining weight (group 2).

Group $1: 30$ days post-partum : $\bullet ; 15$ days post-partum : $; \mathbf{5}$ days post-partum : $\boldsymbol{\nabla}$.

Group $2: 30$ days post-partum : $\bigcirc ; 15$ days post-partum : $\square ; 5$ days post-partum : $\boldsymbol{\nabla}$.

Maximal $\mathrm{LH}$ value and total $\mathrm{LH}$ release were higher in group 1 than in group 2 on each day post-partum (respectively 23.13 and $11.40 \mathrm{ng} / \mathrm{ml}$ for maximal $\mathrm{LH}$ value and 193 and $83 \mathrm{ng} / \mathrm{ml} / 4 \mathrm{~h}$ for total $\mathrm{LH}$ ). But the differences were only significant on days 15 and 30 (table 3 ). 
TABLE 3

Changes in plasma concentrations before and after GnRH injection during the post-partum period (mean \pm SEM)

Group 1 : cows losing weight ; Group 2 : cows gaining weight.

\begin{tabular}{lccccr}
\hline & Group & 5 & \multicolumn{4}{c}{ Number of days after parturition } & mean \\
& & 5 & 15 & 30 & \\
\hline $\begin{array}{l}\text { Number of cows } \\
\text { Sampled }\end{array}$ & 1 & 6 & 9 & 7 & \\
LH level before GnRH & 2 & 9 & 9 & 9 & \\
$\begin{array}{l}\text { Injection (ng/ml) } \\
\text { Mean }\end{array}$ & 1 & $1.89 \pm 0.15$ & $2.21 \pm 0.14$ & $1.82 \pm 0.15$ & 2.00 \\
\hline $\begin{array}{l}\text { Maximal LH value } \\
\text { (ng/ml) }\end{array}$ & 2 & $2.24 \pm 0.15$ & $2.21 \pm 0.09$ & $2.02 \pm 0.13$ & 2.16 \\
Mean & 1 & $6.23 \pm 0.75$ & $26.09 \pm 5.95$ & $33.8 \pm 3.39$ & 23.13 \\
\hline $\begin{array}{l}\text { Total LH release } \\
\text { (ng/ml/4 h) }\end{array}$ & 2 & $5.30 \pm 0.80$ & $12.10 \pm 2.42$ & $16.8 \pm 3.71$ & 11.40 \\
Mean & 1 & $62.54 \pm 5.54$ & $212.52 \pm 55.60$ & $278.38 \pm 73.55$ & 192.57 \\
& 2 & $53.45 \pm 5.47$ & $74.09 \pm 8.79$ & $121.91 \pm 27.42$ & 83.15 \\
\hline
\end{tabular}

The correlation coefficient between total weight variation during the first 30 days post-partum and the maximal LH value was highly significant $(p<0.001)$ on day $15(r=-0.5)$ and on day $30(r=-0.54)$.

\section{Discussion.}

GnRH appeared to induce ovulation in the underfed female and in the normally-fed female, but at day 15 post-partum the quality of the following luteal phase was poor.

The timing of the appearance of the LH peak after $\mathrm{GnRH}$ injection and its profile during the post-partum interval were similar to those described by Kesler et al. (1977) and Fernandes et al., (1978) in the dairy cow, despite repeated injection of the same cows at the different post-partum times in our work. Thus, repetition itself seems to be of minor importance.

Our results clearly demonstrate that delayed first post-partum ovulation induced by underfeeding is not due to the failure of the pituitary to respond to $\mathrm{GnRH}$ with a gonadotrophin surge. In agreement with this observation are the findings that heifers (Beal et al., 1978), ewes (Haresign, 1981), and rats (Campbell et al., 1977) subjected to dietary restriction are more responsive to a $\mathrm{GnRH}$ injection than normally fed animals.

The use of a single dose irrespective of body weight meant that the average dose per $\mathrm{kg}$ of body weight was different between the two groups and might explain the different responses. However the correlation between body weight and LH response was not significant.

It is known that high progesterone concentrations decrease $\mathrm{LH}$ response to GnRH (Beal et al., 1978). The effect of underfeeding can not be explained by differences in progesterone concentration resulting from the presence of corpora 
lutea since the number of cows ovulating was similar for both groups. However, differences in the basal concentrations of progesterone are not known.

It is plausible that, as in rat (Negro-Vilar, Dickerman and Meites, 1971), the low LH concentrations in underfed cattle (Terqui et al., 1981 ; Gauthier et Berbigier, 1982) are due to a decrease in hypothalamic $\mathrm{GnRH}$ content. The higher response to the $\mathrm{GnRH}$ injection could be due to an increase in pituitary LH content in relation with the decrease of $\mathrm{LH}$ in plasma. In other words, the amount of releasable stored $\mathrm{LH}$ in the pituitary may be higher in underfed animals.

Reçu en décembre 1981. Accepté en mars 1983.

Acknowledgements. - We wish to thank Dr. J. Pelletier for the LH assay. We also thank Dr. G. Montgomery for his assistance in translating the manuscript into English.

Résumé. Influence du niveau d'alimentation et de la variation de poids sur la décharge de $\mathrm{LH}$ suite à une injection de $\mathrm{GnRH}$ chez la vache allaitante pendant la période post-partum.

Cette expérience a pour but d'étudier les effets d'une restriction alimentaire, débutant pendant la gestation, sur l'évolution post-partum de la décharge de LH en réponse à une injection de $\mathrm{GnRH}$ chez la vache allaitante. Dix-huit vaches Charolaises multipares reçurent à 5,15 et 30 jours post-partum une injection intraveineuse de $55 \mu \mathrm{g}$ de GnRH. La LH plasmatique fut mesurée pendant les quatre heures suivant l'injection.

Les femelles furent, a posteriori, réparties en 2 groupes selon leur gain moyen quotidien post-partum : gain moyen quotidien négatif (groupe 1), gain moyen quotidien positif ou nul (groupe 2).

La quantité totale de LH déchargée en $4 \mathrm{~h}$ et la concentration maximale de LH après l'injection de $\mathrm{GnRH}$ augmentent pendant la période post-partum quel que soit le groupe considéré. Ces deux valeurs sont plus élevées dans le groupe 1 que dans le groupe 2 ( $p<0,05$ ) à 5,15 et 30 jours post-partum. De plus, la concentration maximale de LH est hautement corrélée avec le gain moyen quotidien, $r=-0,50$ et $r=-0,54$ respectivement à 15 et 30 jours post-partum.

\section{References}

BEAL W. E., SHORT R. E., STAIGMILLER R. B., BELLOWS R. A., KALTENBACH C.C., DUNN T. G., 1978. Influence of dietary energy intake on bovine pituitary and luteal function. J. anim. Sci, 46, 181-190.

COCHRAN W. G., COX G. M., 1968. Experimental design. 2nd ed. John Wiley and Sons Inc., London, Sydney.

CAMPBELL G. A., KURO M., MARSHALL S., MEITES J., 1977. Effects of starvation in rats on serum levels of follicle stimulating hormone, luteinizing hormone, thyrotropin, growth hormone and prolactin; responses to LH-releasing hormone and thyrotropin-releasing hormone. Endocrinology, 100, 580-587.

DUFFOUR J. J., 1975. Influence of post weaning growth rats on puberty and ovarian activity in heifers. Can. J. anim. Sci., 55, 93-100.

FERNANDES L. C., THATCHER W. W., WILLCOX C. J., CALL P., 1978. LH release in response to GnRH during the post-partum period in dairy cows. J. anim. Sci, 46, 443-448.

GAUTHIER D., BERBIGIER P., 1982. The influence of nutritional levels and shade structure on testicular growth and on hourly variations of $\mathrm{LH}$ and testosterone plasma levels in young creole bull in a tropical environment. Reprod. Nutr. Dévelop., 22, 793-801. 
GAUTHIER D., THIMONIER J., 1982. Variations saisonnières de la cyclicité chez la génisse créole, influence de la croissance, de l'âge et de l'émotivité. Reprod. Nutr. Dévelop., 22, 681-688.

HARESIGN W., 1981. The influence of nutrition on the reproduction in the ewe. 2 : effects of undernutrition on pituitary responsiveness to luteinizing hormone-releasing hormone stimulation. Anim. Prod., 32, 257-260.

KALTENBACH C. C., DUNN T. G., KISER T. E., CORAH L. R., AKBAR A. M., NISWENDER G. D., 1974. Release of FSH and $\mathrm{LH}$ in beef heifers by synthetic gonadotropin releasing hormones. J. anim. Sci., 30, 357-364.

KESLER D. J., GARVERICK H. A., YOUNGQUIST R. S., ELMORE R. G., BIERSCHWAL C. J., 1977. Effects of days post-partum and endogenous reproductive hormones on GnRH induced LH release in dairy cows. J. anim. Sci., 46, 797-803.

LAMOND D. R., 1970. The influence of undernutrition on reproduction in the cow. Anim. Breed. Abstr., 38, 359-372.

NEGRO-VILAR A., DICKERMAN E., MEITES J., 1971. Effect of starvation on hypothalamic FSH-RF and pituitary FSH in male rats. Endocrinology, 88, 1246-1255.

PELLETIER J., 1972. Dosages radioimmunologiques de la LH plasmatique ovine et bovine. Coll. INSERM., Les techniques endocrinologiques, Hôpital Saint-Antoine, Paris, 237-255.

TEROUI M., CHUPIN D., GAUTHIER D., PEREZ N., PÉLOT J., MAULÉON P., 1981. Influence of management and nutrition on post-partum endocrine function and ovarian activity in cows. Munich Congr. C.E.E. (in press).

THIMONIER J., 1978. L'activité ovarienne chez les bovins. Moyens d'étude et facteurs de variations. Ann. Méd. vét., 122, 81-92.

YENIKOYE A., MARIANA J. C., LEY J. P., JOLIVET E., TEROUI M., LEMON-RESPLANDY M., 1981. A mathematical model on the cow progesterone pattern : application and proof of breed differences. Reprod. Nutr. Dévelop., 21, 561-575. 